\title{
Is intact fibula a disadvantage in treatment of tibial diaphysis fracture with intramedullary nailing?
}

\author{
Yavuz Kabukçuoğlu, M.D., Sami Sökücü, M.D., Çağrı Özcan, M.D., Kubilay Beng, M.D., \\ Osman Lapçin, M.D., Bilal Demir, M.D.
}

Department of Orthopedics and Traumatology, Baltalimanı Bone Diseaeses Training and Reserach Hospital, İstanbul-Turkey

\begin{abstract}
BACKGROUND: The aim of this study was to compare solitary tibial diaphysis fractures and tibial diaphysis fractures associated with fibula fracture treated with the intramedullary nailing method.

METHODS: Records of 254 patients diagnosed with tibial diaphysis fracture and treated with intramedullary nailing between 2010 and 2013 were examined and 30 patients were included in the study. Group I comprised patients with solitary tibial diaphysis fracture, and Group 2 was made up of patients with tibial diaphysis fractures associated with fibula fracture. Patients in both groups were compared in terms of time to surgery, duration of surgical tourniquet, time to union, and varus, valgus, recurvatum, and antecurvatum deformities of the tibia at final follow-up.
\end{abstract}

RESULTS: No statistically significant difference was found between the 2 groups in time to surgery, duration of surgical tourniquet, time to union, or varus, valgus, recurvatum, and antecurvatum deformities.

CONCLUSION: Results indicated that intact fibula in tibial diaphysis fracture treated with intramedullary nailing was not a disadvantage; it did not affect rate of union or lead to loss of reduction, non-union, or malunion.

Keywords: Fibula; intramedullar nailing; tibia diaphysis.

\section{INTRODUCTION}

Tibia fracture is the most commonly encountered fracture of the long bones. Majority are accompanied by fibula fracture, at the same or different level. However, it is possible that fibula fracture may not occur with tibia fracture in lowenergy injury. ${ }^{[1,2]}$ Fixation of the accompanying fibula fracture for stability is still a matter of debate in the surgical treatment of tibia fracture. While some authors advocate fixing fibula fracture during surgical treatment of tibia fracture, others suggest that this fixation does not have beneficial effect on stability. ${ }^{[3-5]}$ Little information is available on fixation of concomitant or solitary fibula fracture in the surgical treatment of proximal tibial and tibial diaphysis fractures. ${ }^{[5]}$

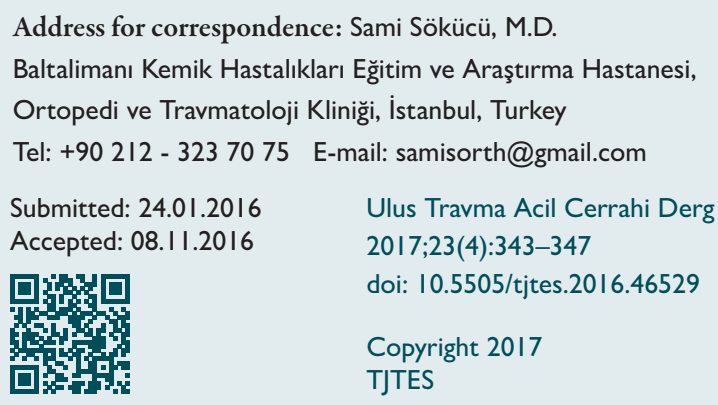

Although intramedullary nailing is considered the gold standard in the surgical treatment of tibial diaphysis fracture, the surgical treatment of concomitant fibula fracture in this region is controversial. While surgical approach is recommended for fibula fracture level with the tibial diaphysis, the approach is avoided if the fibula fracture occurs at a level other than the tibial diaphysis. ${ }^{[5-7]}$

The aim of the present study was to compare time to surgery, duration of surgical tourniquet, and rates of non-union and healing of solitary tibial diaphysis fractures (AO 4.2.AI.I) and tibial diaphysis fractures associated with fibula fracture (AO 4.2.AI.2) treated with the intramedullary nailing method.

\section{MATERIALS AND METHODS}

Data of 254 patients diagnosed with tibial diaphysis fracture and treated with intramedullary nailing between 2010 and 2013 were retrospectively evaluated. Patients who were younger than 18 years of age, had open or pathological fracture, suffered multi-trauma injuries, or who had fracture type other than AO 4.2 Al according to the AO/OTA Classification of Fractures and Dislocations were excluded. Thirty patients (14 males, 16 females) who met the above criteria were included in the study. Mean age was 34 years (range: 18 
to 66 years). Group I comprised patients with solitary tibial diaphysis fracture (AO 4.2 AI.I), and Group 2 was made up of patients with tibial diaphysis fracture associated with fibula fracture (AO 4.2 Al.2).

Anteroposterior and lateral radiographs of the knee and ankle joints of the patients were taken in the emergency department after the injury. Long-leg splints were applied to patients scheduled to be operated on within first 48 hours. Patients whose surgical treatment was planned for after first 48 hours had skeletal traction applied and their surgery was scheduled for the first day possible.

All of the patients had regional anesthesia administered. Reaming was performed before nail insertion and all fractures were reduced with closed technique. Tibial intramedullary nails were inserted with transpatellar approach in all patients while in supine position and without use of traction table by experienced trauma surgeons. Another doctor assisted with traction during reduction procedure. Two static screws were introduced at the proximal and distal fragments of the nail and fixation was achieved. None of the patients required application of plaster splint for further fixation post surgery.

Knee and ankle exercises were initiated on first postoperative day. All patients were mobilized with a pair of crutches on the first day. Patients were reviewed at $2^{\text {nd }}, 4^{\text {th }}, 6^{\text {th }}, 8^{\text {th }}$, and $12^{\text {th }}$ week, and radiographs were taken at $6^{\text {th }}$ and $12^{\text {th }}$ week. Patients were allowed partial weight-bearing with crutches during this period. Clinical and radiological assessments were performed to confirm union, defined as callus formation in 3 cortices and absence of clinical pain. Patients were allowed full weight-bearing thereafter (Figs. I, 2).

Patients in both groups were compared in terms of time to surgery, duration of surgical tourniquet, time to union, and varus, valgus, recurvatum and antecurvatum deformities of the tibia at final follow-up.

Statistical comparisons were made using IBM SPSS Statistics for Windows, Version 20.0 (IBM Corp., Armonk, NY, USA) and Mann-Whitney $U$ test. $P$ value of $<0.05$ was considered statistically significant.
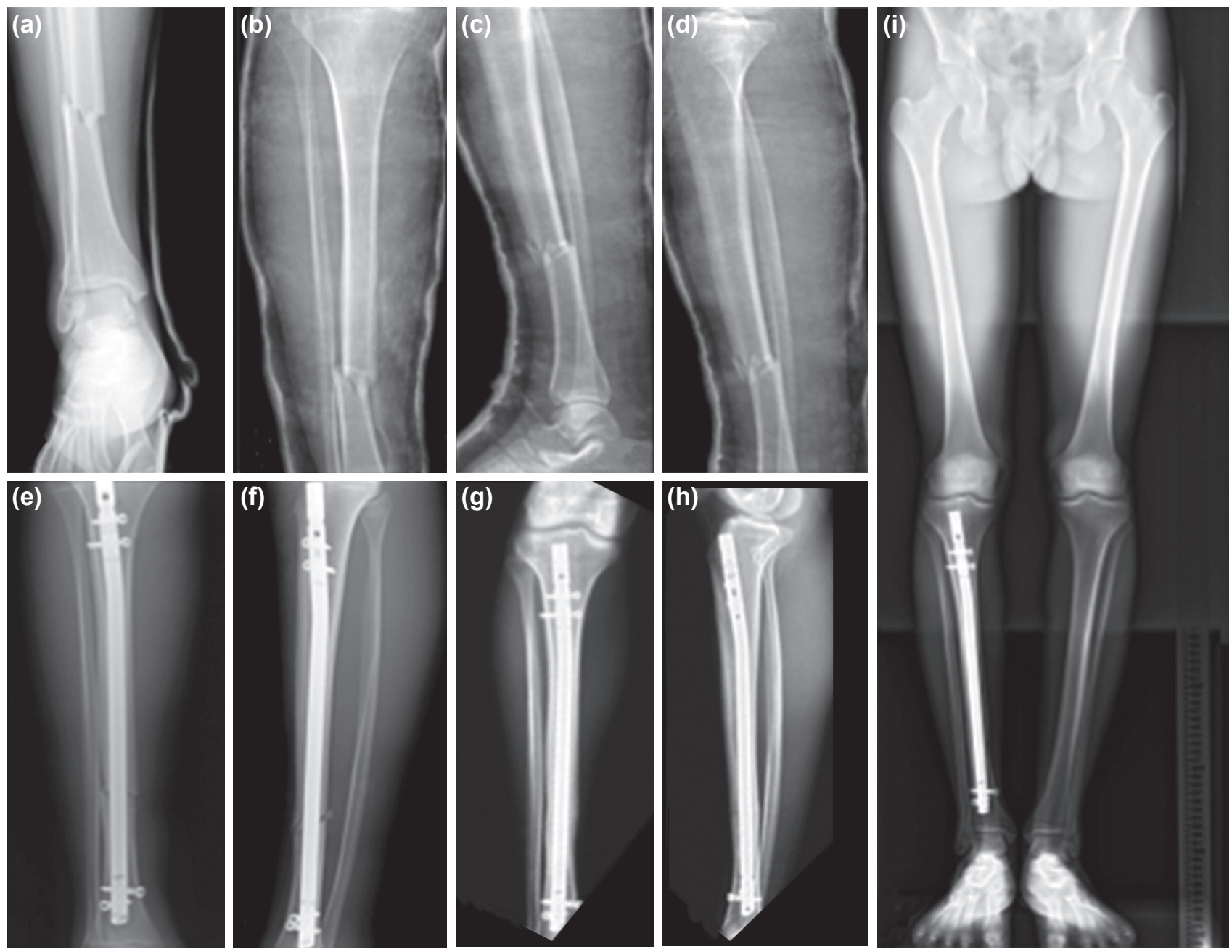

Figure 1. (a-d) Preoperative anteroposterior and lateral radiographs of tibia fracture with intact fibula. (e, f) Postoperative anteroposterior and lateral radiographs. (g-i) Anteroposterior and lateral radiographs and orthoroentgenograms of the patient at last follow-up. 

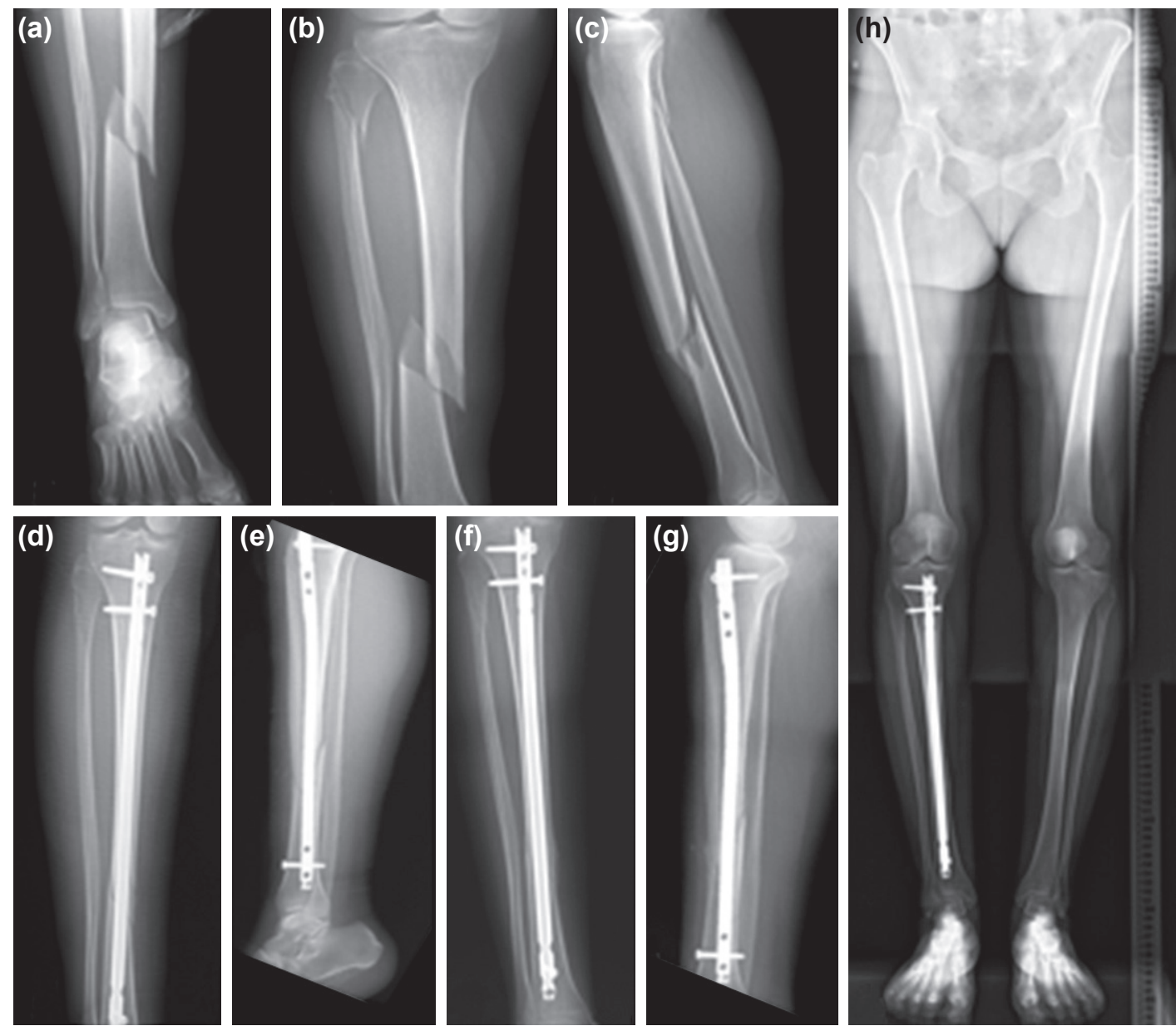

Figure 2. (a-c) Preoperative anteroposterior and lateral radiographs of tibia fracture with fibula fracture. (d, e) Postoperative anteroposterior and lateral radiographs. (f-h) Anteroposterior and lateral radiographs and orthoroentgenograms of the patient at last follow-up.

\section{RESULTS}

Group I, in which the fibula was intact but tibial diaphysis was fractured, consisted of 12 patients ( 8 male, 4 female), and Group 2, in which both the fibula and the tibial diaphysis were fractured, comprised 18 patients ( 8 male, 10 female). Mean age of the patients was 29.4 years (range: 19 to 60 years) in Group I, and 38.6 years (range: 18 to 66 years) in Group 2. Patients in Group I had mean follow-up period of 19.2 months (range: 12 to 36 months), whereas Group 2 patients were followed up for mean of 20 months (range: 12 to 36 months). No statistically significant differences were detected between groups in terms of age or follow-up period $(p=0.751 ; p=0.400)$.

Mean time to surgery was 5.I days (range: 2 to 9 days) for Group I, and 4.I days (range: I to 15 days) for Group 2. There was no statistically significant difference between groups $(p=0.226)$.

Duration of surgical tourniquet was noted as mean of 102 minutes (range: 60 to 150 minutes) in Group I, and 101 min- utes (range: 60 to 160 minutes) in Group 2. Again, no statistically significant difference was found between the 2 groups $(p=0.991)$.

None of the patients experienced intraoperative complication or had early or late infection symptom during follow-up period. Non-union was not observed in any patient. Mean time to union was 75 days (range: 60 to 120 days) in Group I, and 92 days (range: 60 to 180 days) in Group 2. Dynamization was performed due to delayed union in I patient in Group 2.

Table I. Comparison of the groups in terms of varus, valgus, recurvatum, and antecurvatum deformities at final follow-up

\begin{tabular}{lccc}
\hline & Group I & Group 2 & p \\
\hline Varus & $0.78^{\circ}(0-2)$ & $1.12^{\circ}(0-4.2)$ & $=0.869$ \\
Valgus & $0.09^{\circ}(0-1.1)$ & $0.67^{\circ}(0-3.6)$ & $=0.512$ \\
Antecurvatum & $1.09^{\circ}(0-6)$ & $0.35^{\circ}(0-2.3)$ & $=0.400$ \\
Recurvatum & $0.15^{\circ}(0-1.1)$ & $0.86^{\circ}(0-6.7)$ & $=0.981$ \\
\hline
\end{tabular}


Union was clinically and radiologically confirmed on $30^{\text {th }}$ day following dynamization.

Digital orthoroentgenograms of Group I patients taken at final follow-up revealed mean varus angulation of $0.78^{\circ}$ (range: 0 to $2^{\circ}$ ), valgus angulation of $0.09^{\circ}$ (range: 0 to $1.1^{\circ}$ ), antecurvatum angulation of $1.09^{\circ}$ (range: 0 to $6^{\circ}$ ), and recurvatum angulation of $0.15^{\circ}$ (range: $0-1.1^{\circ}$ ). The same values were I. $12^{\circ}$ (range: 0 to $4.2^{\circ}$ ), $0.67^{\circ}$ (range: 0 to $3.6^{\circ}$ ), $0.35^{\circ}$ (range: 0 to $2.3^{\circ}$ ), and $0.86^{\circ}$ (range: 0 to $6.7^{\circ}$ ), respectively, in Group 2. No statistically significant difference was found between groups (Table I).

\section{DISCUSSION}

Treatment of tibial diaphysis fracture with intact fibula is a matter of debate. Although some studies have shown that intact fibula can lead to delayed union in conservative treatment of the tibial diaphysis fracture, others suggest that intact fibula is a good prognostic factor and will increase stability. ${ }^{[2,8,9]}$

Effect of the fibula on stability in the surgical treatment of extra-articular tibia fracture is controversial. Some studies have suggested that absence of or fixation of concomitant fibula fracture in case of extra-articular tibia fracture will increase stability, while others argue that fixation does not provide an additional benefit and is an additional surgical procedure. ${ }^{[10-12]}$ Most of these debates are related to extra-articular distal tibia fracture (AO 4.3); discussion of AO 4.2 diaphyseal fracture is still limited. ${ }^{[5]}$

In a study of tibial diaphysis fractures treated with external fixator, Gotzen et al. reported that fixation of the fibula with plating increased stability. Similarly, in a cadaver study in which the authors fixed tibia fractures with external fixator, Morrison et al. concluded that fixation of the fibula with plating increased stability by 2.2 times in axial loading, but did not have an effect on torsional stability. ${ }^{[1,13]}$

Weber et al. created tibia defects in cadavers for a biomechanical study that investigated axial and bending forces. The authors observed increased movement in the defect area following fibular osteotomy and external fixation of the tibial segmental defects; however, encountered no such increase in movement where they treated the tibial defects with intramedullary nailing. ${ }^{[3]}$

In our study, all patients were treated with intramedullary nailing and no insufficiency in stability due to movement on the fracture line was observed in either group. In addition, there was no statistically significant difference between the 2 groups in rate of union.

It is known that the fibula bears $3 \%$ to $16 \%$ of the load in axial loading. ${ }^{[14,15]}$ It is believed by some that intact or fixed fibula provides additional support to stability in fracture of diaphyseal region of the tibia. Strauss et al. stated that fibula fracture level with tibia fracture decreased stability of the tibial fixation, and that stability was improved with intact or fixed fibula. ${ }^{[7]}$ In our study, none of the patients in Group 2 (with fractured fibula) suffered non-union or deformity due to insufficient stability.

In their series of 38 patients, Bonnevialle et al. treated tibia fractures with intact fibula using reamed intramedullary nail and observed fracture gap increase in 5 patients. They performed dynamization on 6 patients due to delayed union and replaced nail in 2 of these 6 patients due to non-union. ${ }^{[16]}$ None of the patients in Group I (with intact fibula) of the present study experienced either fracture gap increase, delayed union, or non-union.

Retrospective design of this study, limited number of cases in both groups, occurrence of tibial fracture outside the proximal and distal metaphyseal regions, and variety of fracture levels in Group 2 patients are limitations of our study.

In conclusion, fixation of the fibula in tibia fracture is still a matter of debate. Our study results indicated that intact fibula in tibial diaphysis fractures treated with intramedullary nailing will was not a disadvantage; it did not affect rate of union, or lead to loss of reduction, non-union, or malunion.

\section{Conflict of interest: None declared.}

\section{REFERENCES}

1. Sanders RW, DiPasquale TG, Jordan CJ, Arrington JA, Sagi HC. Semiextended intramedullary nailing of the tibia using a suprapatellar approach: radiographic results and clinical outcomes at a minimum of 12 months follow-up. J Orthop Trauma 2014;28 Suppl 8:S29-39. [CrossRef]

2. O'Dwyer KJ, DeVriese L, Feys H, Vercruysse L. Tibial shaft fractures with an intact fibula. Injury 1993;24:591-4. [CrossRef]

3. Weber TG, Harrington RM, Henley MB, Tencer AF. The role of fibular fixation in combined fractures of the tibia and fibula: a biomechanical investigation. J Orthop Trauma 1997;11:206-11. [CrossRef]

4. Egol KA, Weisz R, Hiebert R, Tejwani NC, Koval KJ, Sanders RW. Does fibular plating improve alignment after intramedullary nailing of distal metaphyseal tibia fractures? J Orthop Trauma 2006;20:94-103.

5. Berlusconi M, Busnelli L, Chiodini F, Portinaro N. To fix or not to fix? The role of fibular fixation in distal shaft fractures of the leg. Injury 2014;45:408-11. [CrossRef]

6. Varsalona R, Liu GT. Distal tibial metaphyseal fractures: the role of fibular fixation. Strat Traum Limb Recon 2006;1:42-50. [CrossRef]

7. Strauss EJ, Alfonso D, Kummer FJ, Egol KA, Tejwani NC. The effect of concurrent fibular fracture on the fixation of distal tibia fractures: a laboratory comparison of intramedullary nails with locked plates. J Orthop Trauma 2007;21:172-7. [CrossRef]

8. Teitz CC, Carter DR, Frankel VH. Problems associated with tibial fractures with intact fibulae.J Bone Joint Surg Am 1980;62:770-6. [CrossRef]

9. Leach RE. Fractures of the tibia and fibula. In: Rockwood CA, Green DP (eds). Fractures in Adults, Philadelphia: JB. Lippincott Co, Ch. 


\section{4;2:17}

10. Kumar A, Charlebois SJ, Cain EL, Smith RA, Daniels AU, Crates JM. Effect of fibular plate fixation on rotational stability of simulated distal tibial fractures treated with intramedullary nailing. J Bone Joint Surg Am 2003;85-A:604-8. [CrossRef]

11. Morrison KM, Ebraheim NA, Southworth SR, Sabin JJ, Jackson WT. Plating of the fibula. Its potential value as an adjunct to external fixation of the tibia. Clin Orthop Relat Res 1991;266:209-13.

12. Varsalona R, Liu GT. Distal tibial metaphyseal fractures: the role of fibular fixation. Strat Traum Limb Recon 2006;1:42-50. [CrossRef]
13. Gotzen L, Haas N, Hütter J, Köller W. The importance of the fibula for stability in plate osteosynthesis of the tibia (author's transl). Unfallheilkunde 1978;81:409-16.

14. Lambert KL. The weight-bearing function of the fibula. A strain gauge study. J Bone Joint Surg Am 1971;53:507-13. [CrossRef]

15. Takebe K, Nakagawa A, Minami H, Kanazawa H, Hirohata K. Role of the fibula in weight-bearing. Clin Orthop Relat Res 1984;184:289-92.

16. Bonnevialle P, Bellumore Y, Foucras L, Hézard L, Mansat M. Tibial fracture with intact fibula treated by reamed nailing. Rev Chir Orthop Reparatrice Appar Mot. 2000;86:29-37.

\section{ORIJINAL ÇALIŞMA - ÖZET}

\section{Tibia kırı̆̆ının intramedüller çivi ile tedavisinde, intakt fibula dezavantaj mıdır?}

Dr. Yavuz Kabukçuoğlu, Dr. Sami Sökücü, Dr. Çağrı Özcan, Dr. Kubilay Beng, Dr. Osman Lapçin, Dr. Bilal Demir

Baltalimanı Kemik Hastalıkları Eğitim ve Araştırma Hastanesi, Ortopedi ve Travmatoloji Kliniği, İstanbul

AMAÇ: Çalışmamızın amacı, intramedüller çivi ile tedavi edilen fibula kırı̆̆ının eşlik etmediği tibia diafız kırıkları ile fibula kırığııın eşlik ettiği aynı tip tibia diafız kırıklarının cerrahi süre, kaynamama, yanlıs kaynama ve iyileşme oranlarını karşılaştırmaktır.

GEREÇ VE YÖNTEM: 20I0-20I3 yılları arasında tibia diafiz kırı̆ı̆ı tanısı konulan ve intramedüller çivi ile tedavi edilen 254 hasta geriye dönük olarak incelendi. Çalışma kriterlerine uyan hastalar iki gruba ayrıldı. Her iki gruptaki hastalar, cerrahi öncesi geçen süre, cerrahi turnike zamanı, kaynama zamanları ve son kontrollerindeki tibia varus, valgus, rekurvatum ve antekurvatum deformiteleri açısından karşılaştırıldı.

BULGULAR: Her iki grup arasında cerrahi öncesi geçen süre, cerrahi turnike zamanı, kaynama zamanları ve son kontrollerindeki tibia varus, valgus, rekurvatum ve antekurvatum deformiteleri açısından istatistiksel olarak anlamlı fark tespit edilmedi.

TARTIŞMA: İntramedüller çivi ile tedavi edilen tibia diafizer kıııklarında fibulanın sağlam olması redüksiyon kaybı, kaynamama, yanlış kaynama, ve iyileşme oranları bakımından bir dezavantaj değildir.

Anahtar sözcükler: Fibula; intramedüller çivi; tibia diafiz kırı.

Ulus Travma Acil Cerrahi Derg 2017;23(4):343-347 doi: 10.5505/tjtes.2016.46529 